Cahiers $d u$ MONDE RUSSE

\section{Cahiers du monde russe}

Russie - Empire russe - Union soviétique et États indépendants

$60 / 4 \mid 2019$

Varia

\title{
Eugénie von NIEPPERG, André Beloborodoff, architecte, peintre, scénographe
}

\section{Olga Medvedkova}

\section{OpenEdition \\ Journals}

Édition électronique

URL : https://journals.openedition.org/monderusse/11616

DOI : $10.4000 /$ monderusse. 11616

ISSN : $1777-5388$

\section{Éditeur}

Éditions de l'EHESS

\section{Édition imprimée}

Date de publication : 1 octobre 2019

Pagination : 883-885

ISBN : 978-2-7132-2797-4

ISSN : $1252-6576$

\section{Référence électronique}

Olga Medvedkova, «Eugénie von NIEPPERG, André Beloborodoff, architecte, peintre, scénographe», Cahiers du monde russe [Онлайн], 60/4 | 2019, Выложить онлайн 01 octobre 2019, Наводить справки в 05 janvier 2023. URL: http://journals.openedition.org/monderusse/11616 ; DOI: https:// doi.org/10.4000/monderusse. 11616 


\section{Eugénie von NIEPPERG}

\section{André Beloborodoff, architecte, peintre, scénographe}

Paris : Norma éditions, 2018, 336 p., 350 ill.

В парижском издательстве Норма вышла в свет первая монография, посвященная художнику и архитектору Андрею Белобородову (1886-1965). Этот роскошно изданный при поддержке Фонда Эдуарда и Мориса Сандоз, а также Национального центра книги, более чем 300-страничный дорогостоящий том представляет собой переработанную диссертацию Евгении фон Ньепперг, защищенную в Сорбонне, под руководством профессора Бруно Фукара. Книга разделена на три части, соответствующие трем основным периодам жизни и творчества Белобородова. Первая часть посвящена его детству, юности, началу работы в качестве архитектора и затем эмиграции и первым годам, проведенным в Лондоне (1886-1920), вторая часть - жизни и работе Белобородова во Франции (1920-1934), а третья - новой «эмиграции» в Италию, жизни и работе там (1934-1965). Биография Белобородова и публикация книги сделались возможными благодаря, в частности, работе автора в архиве руководимого Андреем Шишкиным Центра Вячеслава Иванова в Риме, в котором хранится архив Белобородова, в том числе его Воспоминания, на которые Евгения фон Ньепперг опирается в своем исследовании.

В своем предисловии Симон Тексье напоминает, что Белобородов был современником Ле Корбюзье (1887-1965), но что он представляет те стороны культуры 20 века, которые были исключены из истории искусства под воздействием модернизма. Автор книги в своем предисловии также утверждает, что целью ее являлось открытие «другой современности». Благодаря этой публикации, уникальному, как считает автор, искусству Белобородова действительно впервые воздается должное. Даже те, кто не прочтет французский текст, смогут оценить альбом большеформатных, цветных, прекрасного качества репродукций его работ, как графики и живописи, так и построек и интерьеров, проиллюстрированных как современными, так и старыми фотографиями. Что касается текста, то в нем в подробностях воссоздаются основные вехи жизни и творческого пути этого позднего русского неоклассика и палладианца (для сравнения, Жолтовский родился в 1867 году, Фомин в 1872, а наиболее близкий Белобородову Лукомский - в 1884).

Белобородов родился в Туле, в дворянской семье, в 1904 году переехал в Петербург и поступил учиться в подготовительную художественную школу Якова Семеновича Гольдблатта, где познакомился с Александром Яковлевым. Они останутся преданными друг другу до смерти Яковлева в Париже в 1938 году. Поступив в Академию художеств, Белобородов близко сходится с Шухаевым, Рерихом и Лукомским. Он учится под руководством профессора Леонтия Бенуа, путешествует по России, участвует в экспедициях по описанию погибающих памятников русской архитектуры и исполняет ряд обмеров и проектов реставрации неоклассических построек, в частности 
дворца Завадовского. Карьера архитектора начинается с частных заказов, главным образом в аристократических поместьях, как старых так и вновь построенных в неоклассическом стиле. Его приглашают принять участие в создании внутреннего убранства парадных помещений Аничкова дворца. Важной вехой становится заказ на строительство дворца Бобринских (1914-1917) на Английской набережной и внутреннее убранство знаменитого дворца Юсупова. Именно там будет задумано и осуществлено убийство Распутина, свидетелем которого, по его признанию, стал архитектор. Он расскажет об этом позднее, как в своих Воспоминаниях, так и в отдельных статьях. В 1915 году, Белобородов участвует в академическом конкурсе и получает первый приз. Революция прерывает блестяще начатую карьеру. В феврале 1920 года, художник, перейдя границу с Финляндией, покидает Россию. Он останавливает поначалу свой выбор на Лондоне, где работает для труппы Анны Павловой и подолгу гостит у нее в Иви Хауз. В 1920-21 годах, 33-летний Белобородов совершает свою первую поездку по Италии и в течение шести месяцев живет в Риме. Начиная с этого времени, несмотря на то, что основным его местом жительства будет Париж, он неоднократно и подолгу будет жить в Италии. Одной из первых его архитектурных работ станет проект виллы Квитка у Порта Пия в Риме.

Во Франции, в начале 1920-х годов Белобородов обустраивает новый дом для Феликса Юсупова, на этот раз в Булонь-сюр-Сен. Вместе с Яковлевым, он создает там, в частности, театр и планирует парк. Отдельная глава посвящена жизни Белобородова в среде русской эмиграции, его участию в выставках художников Мира искусства. Другая глава рассказывает о роли, которую сыграл в этой среде французский писатель и художественный критик Жан-Луи Водуайе. Водуайе и Анри де Ренье первыми во Франции напишут о Белобородове, в частности в каталогах его персональных выставок 1920-х годов.

Следующая глава посвящена изданиям, иллюстрированным рисунками Белобородова, таким как Залив Салерно с предисловием Поля Валери, Рим с текстом Мориса Палеолога и неосуществленному проекту Римские вилльл. Как и в Петербурге, во Франции Белобородов станет архитектором ностальгически настроенной аристократии. Помимо прочих многочисленных заказов на убранство интерьеров, прекрасно документированных в книге, в начале 1930-х годов он возродит из руин и декорирует замок Коленкур, а также парижскую квартиру его владельцев.

Как и в разделе, посвященном французскому периоду, в третьей, итальянской, части книги автор отводит отдельную главу описанию русской среды в Италии. Здесь важную роль играют Павел Муратов и Вячеслав Иванов, его дети и их друзья. При этом Белобородов дружит и с итальянскими художниками и писателями, такими как братья Де Кирико и Савиньо, Этторе Ло Гатто. Выделяется фигура писателя и критика Мориса Сандоза. Ему и созданным по его заказам работам, посвящена отдельная, самая значительная глава книги. Именно для него Белобородов создаст, помимо прочего, виллу Винья Пеполи у подножия Палатина. История постройки 
этой виллы тщательно документирована и подробно описана в книге. Среди последних проектов архитектора фигурирует также вилла Де Кирико. В заключительных главах автор книги анализирует итальянские станковые фантазии Белобородова, его рисунки и картины, в частности удивительную гуашь Сон фавна и другие работы, в которых римские античные развалины погружаются в метафизические воды реки забвения.

Таким образом, книга Евгении фон Ньепперг является единственной на сегодняшний день монографией о художнике, отличающейся полнотой и детальной проработкой его творческого наследия.

Для читателя, хорошо знакомого с историей русского искусства этого периода, заметны тем не менее два основных недостатка этой работы. Во-первых, таким недостатком является прямолинейное, некритическое использование Воспоминаний художника. Источник недостаточно обстоятельно описан исследовательницей (не указан даже язык, на котором эти Воспоминания написаны), а поданная в нем информация воспринимается ею как очевидная и никоим образом не проверяется. Даже описанные душевные состояния (Воспоминания написаны от третьего лица, что упрощает их цитирование) приводятся как факты биографии: «В то время для Белобородова, “искусство стояло выше жизни”» (с. 17). Из-за этого ряд неточностей неизбежно проникает в повествование. Так, становлению вкуса Белобородова в Петербурге способствует посещение спектаклей Русских сезонов (с. 23), которые, как хорошо известно, в России не показывались. Список таких неточностей можно было бы продолжить.

Другим недостатком книги является то, что ее автор мало знаком с прошлым классической традиции в архитектуре. Рассуждая о возрождении классики Белобородовым, Евгения фон Ньепперг часто не может определить, что же именно он возрождал. Сходство или прямое заимствование конкретных прототипов, античных, ренессансных, палладианских, классических или неоклассических, не выявляется. А лишь такой анализ мог бы дать верное представление как о творческом методе Белобородова, о его эволюции в разные периоды, в разных странах, так и о степени его «уникальности», на которой автор книги настаивает.

\section{Olga Medvedkova}

CNRS, centre Jean-Pépin-ENS 